IНТЕРМАРУМ: історія, політика, культура. - Вип. 6.

UDC 327.7(477): $061.1 \mathrm{CC}$

DOI 10.35433/history.111910

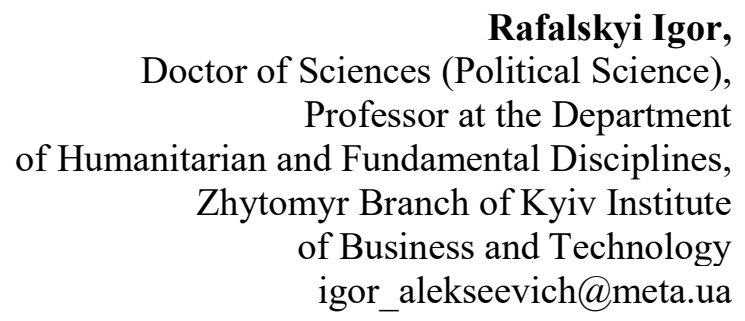

Rafalska Tetiana,

$\mathrm{PhD}$ in History, Associate Professor at the Department of History of Ukraine, Zhytomyr Ivan Franko State University t.1.rafalska@meta.ua https://orcid.org/0000-0002-3259-0514 ResearcherID: http://www.researcherid.com/rid/H-5291-2016

\title{
EUROPEAN CHOICE OF UKRAINE: PREREQUISITES, CONTENTS AND MAIN FACTORS
}

\section{Abstract}

The proclamation of the Act on State Independence of Ukraine is a significant milestone in the history of the Ukrainian people on their way to national self-determination. A new phase of development has begun since 1991 when institutional factors have become crucial. First of all the creation of the Ukrainian state as a new national-state phenomenon takes place. During the years of independencethe process of Ukrainian state development was accompanied by opposition of political forces, which defended the multidirectional vectors of civilization development.

The article deals with the issues of the European choice of Ukraine, as a strategic orientation of the socio-political development of the country, a priority direction of its national-state self-determination. The authors set out to analyze the prerequisites, substantive aspects, major internal and external factors that have influenced Ukraine's choice of a European vector of development. 


\section{INTERMARUM: history, policy, culture. - Issue 6. ISSN 2518-7694 (Print) ISSN 2518-7708 (Online)}

The study is based on the principles of objectivity, dialectics, historicism, social determinism, pluralism. The authors use general scientific methods, including inductive-deductive, analogies, modeling, etc. The comparative method has become an instrument of comparison, and consequently knowledge of the peculiarities of the state-political systems of Ukraine and other countries, which have become the benchmarks in the process of Ukraine's foreign policy self-determination.

The article analyzes the attitude of Ukrainian citizens to the foreign policy and foreign economic development vectors of our country. It is revealed that the general rejection of the multilateralismpolicy significantly changed due to the Orange Revolution, when a sharp polarization occurred in society. The denial of the negative practices of $V$. Yanukovych's regime was manifested in the non-alternative choice of the European vector of Ukraine's development. The period of the presidency of P. Poroshenko has once again proved that only a radical implementation of the political, legal and social norms and standards of the EU will make it possible to overcome the oligarchic traits of the statepolitical system of Ukraine.

Ukraine's European integration aspirations, such as a manifestation of its national-state self-determination, began to gain international legal prominence from the moment when the EU embarked on an "enlargement to the East" course. Ukraine, as a candidate for membership in a united Europe, has to undergo a series of transformations to adapt to EU norms and standards.

However, the European choice as a project of national self-determination was confronted with a number of contradictions and inconsistencies between the mutual expectations of the subjects of this process, which led to the crisis of the whole project and political crises in Ukraine. A number of factors have hindered the implementation of the European integration plan, ranging from the internal instability of Western orientations within the country itself, the unwillingness of European Union members to further enlargement, and the massive opposition from Russia seeking to keep Ukraine in its political orbit.

Key words: self-determination, multilateralism, transformation, adaptation, political space, nomenclature, communist ideology, integration.

Introduction. The proclamation of the Act on State Independence of Ukraine is a significant milestone in the history of the Ukrainian people on their way to national self-determination. A new phase of development has begun since 1991 when institutional factors have become crucial. First of all the creation of the Ukrainian state as a new national-state phenomenon takes place. During the years of independence the process of Ukrainian state development was 
IНТЕРМАРУМ: історія, політика, культура. - Вип. 6.

accompanied by opposition of political forces, which defended the multidirectional vectors of civilization development.

The article deals with the issues of the European choice of Ukraine, as a strategic orientation of the socio-political development of the country, a priority direction of its national-state self-determination. The authors set out to analyze the prerequisites, substantive aspects, major internal and external factors that have influenced Ukraine's choice of a European vector of development.

The study is based on the principles of objectivity, dialectics, historicism, social determinism, pluralism. The authors use general scientific methods, including inductive-deductive, analogies, modeling, etc. The comparative method has become an instrument of comparison, and consequently knowledge of the peculiarities of the state-political systems of Ukraine and other countries, which have become the benchmarks in the process of Ukraine's foreign policy self-determination.

The article analyzes the attitude of Ukrainian citizens to the foreign policy and foreign economic development vectors of our country. It is revealed that the general rejection of the multilateralism policy changed significantly due to the Orange Revolution, when a sharp polarization occurred in society. The denial of the negative practices of $\mathrm{V}$. Yanukovych's regime was manifested in the non-alternative choice of the European vector of Ukraine's development. The period of the presidency of $\mathrm{P}$. Poroshenko has once again proved that only a radical implementation of the political, legal and social norms and standards of the EU will make it possible to overcome the oligarchic traits of the state - political system of Ukraine.

The outline of the research. Ukraine's European integration aspirations, as a manifestation of its national-state self-determination, began to gain international legal prominence from the moment the EU embarked on a course of "enlargement to the East." Countries applying for membership in a united Europe have to undergo a series of transformations to adapt to EU norms and standards. This practice was called "Europeanization". The analytical and scientific achievements of the Ukrainian authors describe the determining directions of the state development in the process of European integration. Researchers $\mathrm{H}$. Yavorska and $\mathrm{O}$. Bohomolov considered the peculiarities of the development of relations between the EU and Ukraine during the 
INTERMARUM: history, policy, culture. - Issue 6.

implementation of the first and second wave of EU enlargement to the East (Yavorska, 2010, p.136). The research works of V. Shkliar (Shkliar, 2002), Z. Hrytsenko (Hrytsenko, 2004) and others are devoted to foreign policy problems of national self-determination.

The substantive aspects of national self-determination are realized in the form of various projects or ideas of social development. One of these projects that accompanies the formation of the Ukrainian nation and state, in particular in the $20^{\text {th }}$ century, is the project of integration into the European cultural and political space. In its primordial forms journalistic appeals, declarations of intent, political slogans - this area of integration can be described as a "European choice". In the conditions of the united Europe, not only as a civilizational but also as a political entity, this choice has become more specific and one of the determining factors of Ukrainian self-determination.

The Pan-European project has acquired a strategic perspective for the Ukrainian nation-state leadership from the very beginning of its practical implementation after the Second World War. While presenting the plan to introduce Ukraine and its interests to the current context of world politics, Ukrainian National Republic Deputy Prime Minister Stepan Vytvytskyi assured his colleagues from the Central Council

The problem of forming our view of the complex called the Russian Empire. There is a view to make the case of Ukraine seperate of this complex. The second view is that the Ukrainian case should be included in the complex of all Eastern European affairs ... However, the most important problem is our inclusion in the United Europe and the PanEuropean concept (Popov, Stepyko, Fadieiev etc. 1999, p.52).

The idea of joining the European integration process is, from the outset, outlined in the context of other integration alternatives as opposed to very unacceptable integration with Russia, combined with a more acceptable but less significant prospect of involving Ukraine in the political and cultural dimension of Eastern Europe.

But if the approach of the emigration government had such a strategy as a pure model that was far from feasible, then the beginning of social transformation in the USSR in the late 1980s unexpectedly put that possibility on the agenda. To tell the truth, the leaders of the communist regimes, who had to deal with that issue, were not quite ready for the challenges of national self-determination. This 
IНТЕРМАРУМ: історія, політика, культура. - Вип. 6.

characteristic can be attributed both to the party nomenclature of the former USSR, who, in the conditions of the destruction of communist ideology and allied statehood, faced the need to develop its own political vision and its own political strategy, as well as to the leadership of the USSR, in particular, its first and last president M. Gorbachov.

By no means abandoning the imperial identity and the intention to preserve the Soviet Union as a single state, Gorbachov began to speak of a "common European home". As a result, it caused some confusion and misunderstanding among his Western partners. After all, Europeans who had already undergone much of the integration path at the time could expect that under this formula would be a new Russian-American alliance, which, within the new redistribution of spheres of influence after the Cold War, would have a common protectorate over Europe (Nyva, 2002). p.12). However, these concerns disappeared with the collapse of the USSR, and the thesis of a "common home" which could combine the Soviet imperial and European interstate models of integration remained a slogan devoid of clear political content.

Thus, the newly independent state of Ukraine had to build for itself its frame of reference of national self-determination and integration, taking into account the experience of being a part of the Russian Empire, and then the USSR, on the one hand, and the realities of the European integration process, which was gaining strength and specific forms, on the other.

At the beginning of Independence, the Ukrainian elite perceived this situation as vague expectations of a quick recognition of Ukrainian identity in the world, finding it a worthy place in the circle of European cultures and national states. Commenting on these high expectations and projects of European integration devoid of specifics, Polish researcher O. Hnatiuk called them "manifestations of megalomania, which testify at least about the hidden complex of inferiority" (Hnatiuk, 2005, p.153).

It is difficult to agree with such a rigid assessment. Rather, it was a certain discrepancy between the realization of oneself and the world, which was the natural consequence of a long period of isolation of Ukrainian cultural and intellectual life in the USSR, which, moreover, was under the close ideological supervision of the Communist Party and the punitive organs of the empire. Of course, it was impossible to expect that under these external conditions a realistic and adequate European integration program of Ukraine could be formulated immediately. The 
INTERMARUM: history, policy, culture. - Issue 6.

Ukrainian project had to mature, undergo certain stages of development, including disappointment, before it could become convincing for the Ukrainians themselves and for their foreign partners.

Former dissident I. Dziuba spoke about the possibility of recognizing Ukraine in the world and in Europe very carefully. $\mathrm{He}$ emphasized good criteria and stringent requirements prevailed in the world, Ukraine wanted to integrate. Agreeing with I. Dziuba overall, we note that the lack of criticality and lowering of standards in culture and politics will seriously threaten the success of the Ukrainian project, as I. Dziuba believed that it would undermine our confidence and our ability to adequate self-esteem (Dziuba, 1990, p. 10).

Attempts to help Ukrainians understand European life, its laws and values, and due to them assess own opportunities and perspectives for inclusion in a particular civilization context can be observed in $\mathrm{M}$. Popovych's journalistic works.

Europe today is still an economic, political and spiritual entity, selfsufficient to some extent. It seeks to preserve and develop this integrity without being locked in, on the contrary, interacting more intensely with the world. At the same time, European attitude towards the outside world remains Euro-centric and selective (Popovych, 1997, p.12).

Thus, the European project of Ukraine envisages adaptation to a fundamentally new system of relations between nations, social groups and individuals. In this system, the convicted "selfishness" prevails, which leaves no chance for success and recognition of the weak, incompetent, uncompetitive. But at the same time, it does not threaten anyone with destruction, humiliation, the need to submit to arbitrariness and the official point of view on social realities.

M. Popovych notes that right, conservative and left, progressive directions in every dimension are possible in Europe even without necessarily entering an irrational "antistructure". Europe has developed a political culture in which opposites confront but do not coalesce and do not necessarily lead to a break in the single political space. A compromise is possible, and this is the living sphere of European politics (Popovych, 1997, p.25).

All these rules of engagement were first understood by the Ukrainian political and intellectual elite and then mastered as their own guidelines. Ukraine's European integration was perceived by its 
IНТЕРМАРУМ: історія, політика, культура. - Вип. 6.

apologists in the context of their intention to change themselves, their way of life, and their habits. But such a change required not only the abandonment of naive hopes for "sincerity" in relationships as the antithesis of "selfishness", but also the acquisition of certain knowledge, skills and habits to think rationally, to reason with partners, to act consistently and effectively to achieve the goals. The corresponding changes in the consciousness, psychology of people, and therefore in the organization of public life, in fact, have been and remain the main criterion for Ukraine's readiness to join the EU.

The expectations of Ukrainians that their "national revival" would be met in Europe with the same enthusiasm as the once "spring of nations" in 1848 were irrelevant. More important for Europe was that this act of national self-determination had the least undesirable consequences that traditionally accompany the creation of new independent states namely violence, minority oppression, cultural unification, aggression against neighbors, etc.

The circumstances of Ukraine becoming independent in 1991 and the policy of the central government in Kyiv were largely met by this hope of the European partners.

M. Popovych mentions that one of the most attractive features of present-day Ukraine for Europe is the tolerance of the new regime in the national question and the lack of ethnic tension, as far as one can judge it (Popovych, 1997, p.62).

It was about the realities that many Ukrainian citizens interpreted as a crisis of state and identity, caused by the policies of the country's leadership, led by President L. Kuchma. After all, the latter came to power in 1994, largely under the slogans of curtailing "Ukrainization" and with the thesis that "the national idea in Ukraine has not worked."

Thus, the European integration project, in some ways, conflicted with the project of national self-determination in the form of national statehood, as it was understood by the more radical part of Ukrainian citizens. However, awareness of this contradiction in public discourse is rather sporadic, insufficiently reflected in analytical researches and, moreover, in public policy documents.

Considering the conflict of the Ukrainian choice of the East-West axis as a key element of national establishment, V. Kremen and V. Tkachenko stated its continuation and even its acquisition of special 
INTERMARUM: history, policy, culture. - Issue 6.

acuity in the conditions of independence. After 1991, scholars believed, "this dilemma began to be viewed in opposition to the ideologies of "Western liberalism" and "Eurasian unity" (Kremen, 1998, p. 431). Thus, the choice was not only between the two strands of integration, but also between its two models and its two understandings of the nature of inter-ethnic relationships.

The choice between East and West for Ukraine is very complicated in the sense that it is practically impossible to make quite clearly and unambiguously under the current conditions, since it inevitably leads to a sharpening of internal confrontation and creates the threat of a split of the country.

During the 1990s, the concept of a "bridge" was also popular among the liberal Ukrainian intellectuals and the leadership of the state, according to which reconciliation between East and West is not only a condition of Ukraine's existence on the world map as an independent state, but also its special mission. M. Popovych expresses a similar idea about Ukraine's European prospects. He believes that Ukraine should unite the worlds, not divide them. It will make us strong, prosperous and form a just order (Popovych, 1994, p. 36).

However, in the context of the internal political instability, unformed identity and lack of the state experience, the path of compromises seems more realistic, the essence of which comes down to the prospect of joining Europe with Russia. A similar integration project is substantiated by the authors of "Ukraine: the Path to itself", V. Kremen and V. Tkachenko, who have modeled the East-West civilization synthesis within the framework of the cultural and political paradigm in the space of "Great Europe "(Kremen, 1998, p. 431). Nevertheless, the authors of the analyzed work have come to the conclusion that the Western vector prevails over the eastern one as a strategic decision and a condition for a full national existence and development of independent Ukraine.

Analyzing the international situation around our country in the mid1990s, V. Kremen highlights the factors, which caused the Ukrainian authorities to adopt a strategic course for European integration, the rise of the Eurasian wave in Russia; raising the cultural confrontation to the level of civilizational split between East and West; an unprecedented wave of mobilizing fundamentalism (Kremen, 2013, p. 405). 
IНТЕРМАРУМ: історія, політика, культура. - Вип. 6.

Thus, in the context of the consolidation of the ruling regime and national mobilization in the Russian Federation, Ukraine's "European choice" became a natural reaction to the threat of marginalization, loss of national identity and the transformation into a "gray zone" of permanent conflict between Russia and the West.

This situation, which emerged in the second half of the 1990s and became particularly acute in the early 2000 s, was already fundamentally different from the position of Ukraine during the period of independence. If at that time the main obstacle for integration into the European space were differences in the expectations of the intellectual elite of Ukraine and its European partners, then, under the pressure of Russia's reintegration aggression, the Ukrainian ruling elite was already forced to view the European vector as the only possible way of the maintenance of sovereignty and the formation of their own international subjectivity

Since V. Putin came to power in Moscow the problem of Ukrainian choice has become particularly acute and urgent. In the new conditions, the Ukrainian elite has already had to make geopolitical and civilizational choices under the pressure of very serious foreign policy factors, among which the leading role belonged to the policy of the Russian Federation.

The activity of Putin's new policy and the continued uncertainty of Ukraine have led to a change in the strategy of leading geopolitical players, primarily the United States.

If earlier we could rely on the principle of the position of the West and, above all, the United States, now all this construction is called into question. Washington's de facto recognition of Russia's right to "natural domination" in the post-Soviet space is directly relevant to RussianUkrainian relations (Halchynskyi, 2001, p. 123).

A. Halchinsky comes to the logical conclusion that in this, almost hopeless, from the point of view of geopolitics, situation there is the need to find a new partner and support in the outside world. This is Western Europe, which understands that any new annexation of Ukraine by Russia will lead to serious destabilization on the European continent (Halchynskyi, 2002, p.124).

Identification with Europe, in this formulation of the question, was no longer a product of romantic expectations and free choice of a value system, but rather a rigidly determined choice or even the only chance of self-preservation. In this new modality, the European choice is linked 
INTERMARUM: history, policy, culture. - Issue 6.

not only to geopolitical trends, but to such a phenomenon of civilizational development as globalization. Assessing the extent and nature of the external influence on the domestic political processes in Ukraine, in particular, the 2004 election process, the experts of the O. Razumkov's Center emphasized that the "lonely country", in the face of increased global integration processes, virtually deprived of the chance of survival. This threat became especially relevant for Ukraine as it entered the phase of economic growth and stabilization of the social sphere, which occurred at the turn of the 2000s (National Security and Defense. 2004, p.56).

At this new stage of awareness of national tasks and national interests, in particular, in the context of the idea of a "European choice", the Ukrainian elite finds new realities and new conditions for realizing their integration intentions. However, there remains a biased attitude of Western Europeans towards Ukraine, their unwillingness to consider Ukrainians as civilly related partners.

We believe, it is no longer about the need for the Ukrainian side to mature or to acquire certain partner conditions such as responsibility, predictability, etc. This is a fundamentally different cultural, ideological, and psychological distinction that creates a barrier to the European aspirations of Ukrainians. Yu. Shcherbak argues that our current difficulties in integrating Ukraine into Europe are rooted not only in the internal Ukrainian situation but also, to a greater extent, in our attitude towards the "true" Europeans united in the European Union, which is something like the new Holy Roman Empire. If the EU can forgive post-socialist sins for Poles, Magyars and Czechs, it will never forgive Ukrainians (Shcherbak, 2003, p.326).

Taking these factors into account the ideologues of Ukraine's European choice have to construct a distinct supranational identity that mediated accession to the United Europe, the identity of Central and Eastern Europe.

The logic of geopolitical transformations, that after the last wave of EU enlargement actually has formed the line of confrontation between civilizations of the West and the East, destroyed this hope of the Ukrainians. Hopes for Central and Eastern European solidarity are utopian. The interests of the post-Soviet and post-communist countries of the region temporarily coincided at the moment of the collapse of the 
IНТЕРМАРУМ: історія, політика, культура. - Вип. 6.

USSR, but similarly situationally, according to the international situation, diverged at the moment when more powerful integration incentives began to operate.

The threat of isolation that has arisen because of the destruction of strategic alliances with Central European partners has prompted another review of the European project and its place in the context of national self-determination. The triangle of choice between Russia, Europe and the USA, which contained not so many possibilities but threats to national sovereignty, has become relevant again. This is especially true of the Eurasian integration project, which recreates the former imperial identity and the subordination of national interests to the restored Union center (Havrylyshyn, 2002, p. 8).

Later, analyzing the prospects B. Havrylyshyn has emphasized that there are also external prerequisites for successful transformation of Ukraine into a "normal state". Over the next 20 years, our country must become an EU member or at least be at the final stage to that (Havrylyshyn, 2009 p.241).

Starting from attempts to direct the drift of the Ukrainian political nation toward a restored Russian empire, a Ukrainian researcher, M. Mykhalchenko, offered his own understanding of the very principle of legitimizing the project in question. It is based on the concept of civilization as a separate historical and cultural entity, which, in particular, determines the political choice of the nations that make up it. Since, from the point of view of apologists of Eurasianism, "Slavic Brotherhood", Orthodox Union and other reintegrating Russian concepts, the Ukrainian nation as a subject of world order is a fiction, so it does not have the right to create its own state. In order to substantiate the opposite thesis, M. Mykhalchenko put forward an "axiom that does not require proof and self-justification", and its content includes "the existence of microcivilization namely Ukrainian, which is part of Slavic and world civilization" (Mykhalchenko, 2004, p.29).

The ambiguity of Ukraine in the world and European system of cultural and political coordinates is a consequence of its intermediate state between the civilizations of Western European and Eurasian ones. However, from this point of view, according to M. Mykhalchenko, there are not only disadvantages and risks for statehood and national sovereignty. Ukraine "can, in its self-determination as a local 
INTERMARUM: history, policy, culture. - Issue 6.

civilization, acquire samples, norms of life in both civilizations, enriching its own." This status opens new perspectives in the integration dimension as well:

The ambivalence of many characteristics of Ukraine's public life allows it to enter modern global processes and reverse our neighbors more softly (Mykhalchenko, 2013, p. 307).

The attempt to avoid civilizational choices and unambiguous identification with the West or the East has drawn analogies to the traditional concept of "bridge", which some intellectuals and politicians have sought to dispel with the contradictions of national selfdetermination in the early years of independence. The main disadvantage of this scheme is that it does not work in two cases: a) if civilizations do not seek mutual understanding or b) if they find it without the mediation of "limitrophes". The attempt to model another, third option, which is only advantageous and acceptable to Ukraine as a "local civilization", is faced with a large number of conventions. It is possible to agree with the authors of the monograph "Ukraina raskolotaya $\mathrm{V}$ sebe: ot Leonidii do Viktorii" that "the conflict of civilizations", according to the researchers, should be transformed into "cooperation of civilizations" where Ukraine, which is in the area of collision, interaction of civilizations, must determine and defend their role. However, the specific role of Ukraine should not contradict the partnership with the West or the East (Mykhalchenko, \& Andrushchenko, 2012, p. 327).

The analysis of the real state of affairs and tendencies of international life in the European geopolitical dimension makes one acknowledge the palliative nature of the "limitrophic" project, which is a temporary substitute for a full-fledged orientation to the West, provided that it has not yet had the conditions in either Ukraine or the United Europe. M. Mykhalchenko emphasizes the importance of methodological aspect of his concept in comparison with practical. The methodological concept aims to compensate for the shortcomings of the Western vector of Ukraine's development in its more unambiguous versions, since it attempts to force Ukraine's inclusion in the "Western world" by ignoring its internal essential civilizational characteristics, may prove counterproductive and disorganizing (Mykhalchenko, 2004, p.327). 
IНТЕРМАРУМ: історія, політика, культура. - Вип. 6.

An analysis of the main components of Ukrainian public discourse related to the representation of the European integration idea in the political sphere is made in the book by $\mathrm{H}$. Yavorska and O. Bohomolov (Yavorska, Bohomolov, 2010). Researchers have noted the difference in interpretation of the most basic concept of "integration". In the context of the European Union foundation, it means tightening the relations between the constituents of the union, which quite accurately reflects the content of the English phrase European integration. Instead, the Ukrainian phrase has a different semantic connotation: it denotes a movement oriented in the direction from outside the union to its middle (Yavorska, 2010, p. 115). Both variants correspond to the literary norm of using the word integration, but the phenomenon of transferring the term from one context to another and, in the end, distinguishing it, is a bright illustration of the mismatch of thesauruses and the disparity of expectations associated with it.

Researchers have also demonstrated the complex dynamics of the basic semantic units that have appeared in the discourse of European integration on the Ukrainian media materials. Thus, the original metaphorical construction "the way to Europe" was soon replaced by a semantically obscure "course for European integration" (Yavorska, 2010, p. 123). H. Yavorska and O. Bohomolov explaine this meaningful replacement of unfavorable circumstances of the development of relations between the EU and Ukraine during the implementation of the first and second wave of EU enlargement to the East. But it also draws attention to the fact that once selected techniques of conceptualizing the space of international relations are still difficult to adjust. Therefore, the adoption by the official political discourse of the formula of "movement on the course" to some extent not only reflected the absence of a real path to Europe, with its attributes in the form of temporal and meaningful landmarks, shades, etc., but also programmed this situation for the future.

According to the observations of H. Yavorskaya and O. Bogomolov, the key motive of Ukrainian public reflections on Europe and the prospects for our country's accession to the EU is the "semantics of desire", which reflects a specific communicative setting - rather a focus on experiencing the desire to enter Europe, than means of achieving the intended purpose (Yavorska, 2010, p.123). 
INTERMARUM: history, policy, culture. - Issue 6.

The predominance of the emotional and mythological component in covering the problems of European integration of Ukraine and other foreign policy problems of national self-determination have been stated by researchers of the information space and the activities of its subjects (Shkliar (2010), Hrytsenko (2004)). Therefore, we can note in general that the European choice as a project of national self-determination has been confronted with a number of contradictions in the nature of modern national self-awareness and with the discrepancies between the mutual expectations of the subjects of this process. Resolving these contradictions and overcoming misunderstandings take a long time and effort to rationalize the project itself and approaches to its implementation. Until this happens, stereotypes and metaphors designed to eradicate the cognitive dissonances and real contradictions of choices that need to be made to the community will continue to dominate in public opinion.

Instead, current EU-Ukraine relations suffer from a "crisis of confidence". Certain events and processes suggest that you should not expect a shift in the coming years. First, the spread of the debt crisis (Greece, Ireland, Portugal) and the problems of the functioning of the euro zone have struck one of the foundations for the integration of European countries namely the economic one. Secondly, aid to weaker members polarizes public opinion in EU countries and has led to increased dissatisfaction among the population and major donor countries and countries receiving the aid, as they have been cutting spending, which has a negative impact on the social sphere. Thus, another important foundation for European integration, the idea of the solidarity of European peoples, is doubtful (Kopiyka, 2012).

Thought the situation with the process of signing the Association Agreement changed in 2013 the peculiarity of the Ukrainians' awareness of the European integration perspective as a certain dream belonging to the sphere of passive "desires" rather than real "actions" is reflected in the dynamics of public opinion, which has been recorded by sociological opinion.

According to these data, there are many contradictions in the attitude of the Ukrainians to the EU and the prospects of gaining membership, which can only be explained by the high degree of mythologization of this issue. Thus, in the period from 2000 to 2005 , when the country's political leadership took very active steps towards 
IНТЕРМАРУМ: історія, політика, культура. - Вип. 6.

European integration, the number of citizens who considered it necessary to join the EU in the next 5 years decreased from $52 \%$ to $21.5 \%$. And, for example, in April 2012, when $51.3 \%$ of those polled thought that the new enlarged Agreement should fix a clear prospect of Ukraine's EU membership, only $41.5 \%$ thought that Ukraine would benefit from such membership. At the same time, the share of Ukrainian citizens who were ready to answer the question "Do you feel European, feel your belonging to the culture and history of the European community?" remained in the same period 2005-2007, when the last wave of EU enlargement took place was within $36 \%-32 \%$. Similar paradoxes demonstrate the results of other sociological studies conducted on this topic (Razumkov Center, 2012).

The decisive factor in the success of national choice and consistency in its implementation are the characteristics of the public communication that have accompanied the emergence and dissemination of relevant social ideas. The underdevelopment of the ideological component in the life of Ukrainian society has been an obstacle to setting and solving urgent tasks, including the field of national integration strategy.

Such a strategy should obviously have some core in the form of a top priority that is recognized nationally and not a subject to revision with a changing political environment. At the same time, such a strategy should have a technological component that would answer the question how the foreign policy integration priorities will be realized and the respective goals achieved. Finally, the third necessary feature of European integration strategy, like any other, is to take into account the dynamics and main vector of foreign policy transformations which must be adequate for the relevant project.

The signing of the Association Agreement between Ukraine and the $\mathrm{EU}$ is an important event for both internal political development and relations with the EU. At the same time, the importance of this Agreement and the risks associated with its implementation should be really assessed. After all, real or perceived risks also delayed the signing of this Association Agreement by the Government of M. Azarov during the Eastern Partnership Summit in Vilnius on November 28-29, 2013. This was the main cause of the social explosion in Ukraine, the 
INTERMARUM: history, policy, culture. - Issue 6.

"revolution of dignity" and, eventually, has changed political power in the state.

The process of preparation for the implementation of the Association Agreement as a mechanism for the realization of the European Choice Project of Ukraine began in 2009, when the Association Agenda was approved and entered into force. It was to become a practical instrument in preparation for the implementation of the EU-Ukraine Association Agreement. In order to implement the Association Agenda, the Government of Ukraine approved the plans for the implementation of the Agenda and developed certain mechanisms for its implementation. According to the government information on the Implementation of the EU-Ukraine Association Agenda for 2013, some progress has been achieved accordingly to most indicators (Kopiyka, 2012). Some progress, when translated from the bureaucratic language to ordinary, means practically no progress.

Thus, it is possible to identify several essential features of Ukraine's European Choice project as it developed in the context of independence.

The idea of inclusion in the European cultural and political space is based on a set of historical and cultural prerequisites. These prerequisites are that Ukraine is traditionally in the circle of European public perceptions, sharing ideas, norms and values in common with the rest of Europe. The European character of Ukrainian national selfdetermination is based on this.

Integration into the European space has been identified as a priority of the national strategy of self-determination already in the period of state independence by a number of ideologues of the Ukrainian project, starting with M. Khvylovyi, V. Lypynskyi and ending with the figures of Ukrainian emigration of the post-war period. Therefore, the definition of the European vector as the main landmark of national development and emancipation in the circle of state nations was a natural consequence of the declaration of independence of Ukraine.

Initially, the European integration project had a cultural and somewhat abstract meaning. It was implemented in specific rhetorical formulas of "return to Europe" and was accompanied by reflections on whether someone was "waiting" for Ukraine in Europe. Critics of this approach have drawn attention to the need to take into account the norms of European co-operation that the Ukrainian intellectual and 
IНТЕРМАРУМ: історія, політика, культура. - Вип. 6.

political elite, and with it, the whole society, should absorb in order to adequately interact with and be properly apprehended and appreciated by European partners.

Conclusions. The failure of mutual expectations and differences in the "agenda" of the two projects such as Ukrainian national self-determination in its classic romantic forms, on the one hand, and pragmatic European unification around common economic interests, on the other, has led to a kind of freezing of the European integration project. Only the beginning of the EU's enlargement to the East by joining the countries of the former socialist camp has prompted Ukraine to consider the prospects of membership in the organization more substantially and interestedly.

The threat of civilizational isolation and geopolitical marginalization of Ukraine, which has become ever more apparent in the process of EU enlargement to the East and the simultaneous intensification of Russia's reintegration pressure, has led to the emergence of a kind of plan of entry into the EU in Ukrainian intellectual and political environment, which envisaged the entry into force of political international factors. The main role in this regard was given to the potential influence of the USA on the European partners, for the sake of their compassion on Ukrainian aspirations. Such an impact was made possible by the accelerated integration of Ukraine into NATO. A number of factors have been hindering the implementation of this plan, ranging from the internal instability of Western orientations in Ukraine itself, the unwillingness of EU members to further enlargement, to massive opposition from Russia.

In the Ukrainian European integration discourse, all these conflicts have caused conflicting phenomena and led to the emergence of new, mutually exclusive approaches. On the one hand, there has been an increase in anti-Western sentiment in Russian-speaking regions of the country, which have experienced strong propaganda influence from Russia during this period. On the other hand, the emergence of new concepts of international, geopolitical and even civilizational subjectivity of Ukraine, which would allow to avoid the contradictions of the European integration course from the agenda of national selfdetermination for a later period.

Components of European integration policies that have been implemented by various governments and presidents of Ukraine in the 
INTERMARUM: history, policy, culture. - Issue 6.

ISSN 2518-7708 (Online)

context of changes in the concept of national self-determination during 2004-2014 require further studies.

\section{BIBLIOGRAPHY}

Dziuba, I. (1990). Ukraine and the world. Science and Society, 818. [In Ukrainian].

Halchinskyi A. (2001). Contradictions of reforms: in the context of the civilization process. Kiev: Ukrainian Propies, 320. [In Ukrainian].

Halchinskyi, A. (2002). Ukraine is at the crossroads of geopolitical interests. Kiev: Knowledge of Ukraine, 180. [In Ukrainian].

Havrylyshyn, B. (2002). Ukraine between East and West, North and South: Geopolitical Opportunities and Constraints. State Building. 2002, 7-12, 26-33. [In Ukrainian].

Havrylyshyn, B. (2009). To effective societies. Report to the Roman Club. Kiev: Pulsars, 248. [In Ukrainian].

Hnatyuk, O. (2005). Farewell to the Empire: Ukrainian Identity Debates: trans. from the pol. Kiev: Criticism, 528. [In Ukrainian].

Hrytsenko, Z. (2004). Peculiarities of Constructing Modern Ukrainian Identity at the End of XX - beg. XXI century. Grani, 121127. [In Ukrainian].

Information on the 2013 Implementation of the EU-Ukraine Association Agenda. (2013). The Ukrainian part of the Committee on Senior Officials Implementation of the EU-Ukraine Association Agenda.

http://www.kmu.gov.ua/control/uk/publish/frticle\%3FshowHidden=1\&a $\mathrm{rt}$ id $=243281941 \&$ cat $\mathrm{id}=22345338 \&$ cti $\mathrm{me}=1266423569791$. [In Ukrainian].

Kopiyka, V. (2012). European integration as a strategy for Ukraine's development. Ukraine's Independence in the Global World: Vectors of the 21st Century. 165-171. [Iin Ukrainian].

Kremen, V. (1998). Ukraine: the way to yourself. Problems of social transformation. Kyiv: Print Center, 448. [In Ukrainian].

Kremen, V. (2013). Ukraine: Identity in the Age of Globalization (Outlines of a Methodological Study. Kiev: Knowledge of Ukraine, 321. [In Ukrainian]. 
IНТЕРМАРУМ: історія, політика, культура. - Вип. 6.

Mykhalchenko, K., \& Andrushchenko, V. (2012). Ukraine split in itself: from Leonidia to Victoria. (in 2 volumes.). Kiev: National Academy of Sciences of Ukraine. [In Ukrainian].

Mykhalchenko, M. (2004). Ukraine as a New Historical Reality: Europe's Reserve Player. Drohobych: VF Renaissance, 488. [In Ukrainian].

Mykhalchenko, N. (2013). Ukrainian regional civilization: past, present, future. Kiev: National Academy of Sciences of Ukraine, 340. [In Ukrainian].

National Security and Defense (2004). Special Issue "External Factor in the 2004 Presidential Election", 8-27.

Niva, J. (2002). Europe after 1989, a broken dream. Europe of metaphysics and potatoes. Kiev: The Spirit and the Letter, 8-27. [In Ukrainian].

Popov, B., Stepyko M., Fadieiev V. and others (1999). Nation among nations: meanings and meanings. HAH of Ukraine, Institute of Philosophy. GS Skovoroda. Kiev, 108. [In Ukrainian].

Popovich, M. (1994). What's ahead: European or fundamentalism? Genesis, 1, 35-38.

Razumkov

Center.

(2012).

http://www.razumkov.org.ua/ukr/socpolls.php?cat_id $=46$

[in Ukrainian].

Shcherbak, Y. (2003). Ukraine: Challenge and Choice. Prospects of Ukraine in the Globalized World of the 21st Century. Kiev: The Spirit and the Letter, 578. [In Ukrainian].

Shklar, V. Mass Media and the Formation of European Thinking: National and World Context. Universum, 9-10, 29-30. [In Ukrainian].

Yaworska, G. (2010). Uncertain Object of Desire: EUROPE in Ukrainian Political Discourse. Kyiv: Dmitry Burago Publishing House, 136. [In Ukrainian].

\section{Рафальський Ігор, Рафальська Тетяна. СВРОПЕЙСЬКИЙ ВИБІР УКРАЇНИ: ПЕРЕДУМОВИ, ЗМІСТ І ОСНОВНІ ЧИННИКИ}

\section{Анотація}

Проголошення Акту про державну незалежність Украӥни - важлива віха на шляху украӥнського народу до національного самовизначення. Від 


\section{INTERMARUM: history, policy, culture. - Issue 6. ISSN 2518-7694 (Print) ISSN 2518-7708 (Online)}

1991 р. розпочинається новий етап розвитку, на якому вирішальної ролі набули інституційні чинники. Насамперед, йдеться про створення Української держави як нового національно-державного феномену. У роки незалежності процес розбудови Української держави супроводжувався протистоянням політичних сил, щуо відстоювали різноспрямовані вектори цุивілізаційного розвитку.

В статті розглядаються питання європейського вибору Украӥни, як стратегічного оріснтиру суспільно-політичного розвитку країни, пріоритетного напряму ї̈ національно-державного самовизначення. Автори поставили за мету проаналізувати передумови, змістовні аспекти, головні внутрішні та зовнішні чинники щзо вплинули на обрання Україною європейського вектору розвитку.

Дослідження трунтується на принциипах об'єктивності, діалектики, історизму, соціального детермінізму, плюралізму. Автори використали загально-наукові методи, зокрема індуктивно - дедуктивний, аналогї, моделювання тощзо. Компаративний метод став інструментом порівняння, а відтак пізнання особливостей державно-політичних систем України й інших країн, які поставали орієнтирами в процесі зовнішньополітичного самовизначення України.

В статті проаналізовано ставлення громадян України до зовнішньополітичних та зовнішньоекономічних векторів розвитку нашої країни. Виявлено, щзо загальне неприйняття політики багатовекторності, істотним чином змінилося завдяки Помаранчевої револючії, коли в суспільстві відбулася різка поляризачія. Заперечення негативних практик режиму В. Януковича проявилось в безальтернативності вибору європейського вектору розвитку Украӥни. Період президенства П. Пороченка ще раз довів, щуо тільки радикальна імплементація політичних, правових і сочіальних норм і стандартів $С C$ уможливить подолання олігархічних рис державно - політичної системи України.

Свроінтеграційні прагнення України, як прояв ї̈ національнодержавного самовизначення, почали набувати міжнародно-правової визначеності з того моменту, коли в СС було взято курс на «розширення на Схід». Україна, як претендент на членство в об'єднаній Свропі, має пройти низку трансформацій для адаптації до норм і стандартів ЄС.

Однак, європейський вибір як проект національного самовизначення зіткнувся з низкою суперечностей та з невідповідністю взаємних очікувань суб'єктів изього процесу, щчо призвело до кризи всього проекту та політичних криз в Україні. На перешкоді реалізації євроінтеграчійного плану постала низка чинників - від внутрішньої нестабільності орієнтацій на Захід у самій краӥні, неготовності членів Свропейського 
IНТЕРМАРУМ: історія, політика, культура. - Вип. 6. ISSN 2518-7694 (Print)

ISSN 2518-7708 (Online)

союзу до подальшого розширення, й до масованої протидї з боку Росії, яка прагне утримати Украӥну у своїй політичній орбіті.

Ключові слова: самовизначення, багатовекторність, трансформація, адаптація, політичний простір, номенклатура, комуністична ідеологія, інтеграція.

\section{Igor Rafalski, Tetiana Rafalska. EUROPEJSKI WYBÓR UKRAINY: PRZESLANKI, TREŚĆ I GLÓWNE CZYNNIKI}

\section{Streszczenie}

Ogłoszenie Ustawy o Niepodległości Ukrainy jest ważnym krokiem na drodze narodu ukraińskiego do samostanowienia narodowego. Od 1991 r. rozpoczęła się nowa faza rozwoju, w której czynniki instytucjonalne staty się kluczowe. Przede wszystkim chodzi o stworzenie państwa ukraińskiego jako nowego fenomenu państwa narodowego. W latach niepodległości procesowi rozwoju państwa ukraińskiego towarzyszyła konfrontacja sit politycznych, które bronity wektory rozwoju cywilizacyjnego, idace w różne strony.

Artykut dotyczy kwestii europejskiego wyboru Ukrainy, jako strategicznego ukierunkowania rozwoju społeczno-politycznego kraju, priorytetowego kierunku samostanowienia państwa narodowego. Autorzy postanowili przeanalizować przesłanki, aspekty treściowe, główne czynniki wewnętrzne $i$ zewnętrzne, które wplynęty na wybór przez Ukraine europejskiego wektora rozwoju.

Badanie opiera się na zasadach obiektywności, dialektyki, historyzmu, determinizmu społecznego, pluralizmu. Autorzy zastosowali ogólne metody naukowe, zwłaszcza indukcyjne- dedukcyjne, analogie, modelowanie i inne. Metoda porównawcza stała się narzędziem porównania, a zatem idzie znajomości specyfiki państwowo-politycznych systemów Ukrainy i innych krajów, które stały się punktami odniesienia $w$ procesie samostanowienia Ukrainy w polityce międzynarodowej.

Artykut analizuje stosunek obywateli Ukrainy do wektorów rozwoju polityki i gospodarki zagranicznej naszego kraju. Jasne, że ogólne odrzucenie polityki wielu wektorów zmieniło się dzięki Pomarańczowej Rewolucji, kiedy nastapiła ostra polaryzacja $w$ społeczeństwie. Zaprzeczanie negatywnych praktyk rezimu W. Janukowicza przejawiało się $w$ pozbawionym alternatywności wyborze europejskiego wektora rozwoju Ukrainy. Okres, kiedy prezydentem byt P. Poroszenko, po raz kolejny udowodnit, że tylko radykalna implementacja norm politycznych, prawnych $i$ spolecznych UE pozwoli przezwyciężý oligarchiczne cechy państwowo-politycznego systemu Ukrainy. 


\section{INTERMARUM: history, policy, culture. - Issue 6. ISSN 2518-7694 (Print) ISSN 2518-7708 (Online)}

Pragnienia Ukrainy do integracji europejskiej, będace przejawem samostanowienia państwa narodowego, zaczęły nabywać międzynarodowego znaczenia prawnego od momentu, gdy UE rozpoczęla kurs "rozszerzenia na wschód". Ukraina jako kandydat do członkostwa w zjednoczonej Europie musi przejść szereg transformacji, aby dostosować się do norm i standardów $U E$.

Jednak europejski wybór jako projekt narodowego samostanowienia napotkat szereg sprzeczności $i$ rozbieżności między wzajemnymi oczekiwaniami podmiotów tego procesu, co doprowadziło do kryzysu całego projektu i kryzysów politycznych na Ukrainie. Realizacja planu integracji europejskiej utrudniona jest przez szereg czynników, mianowicie od wewnętrznej niestabilności zachodnich orientacji w samym kraju, niechęci członków Unii Europejskiej do dalszego rozszerzenia oraz masowej opozycji ze strony Rosji dażacej do utrzymania Ukrainy na swojej orbicie politycznej.

Stowa kluczowe: samostanowienie, wiele wektorów, transformacja, adaptacja, przestrzeń polityczna, nomenklatura, ideologia komunistyczna, integracja.

The article was received 08.30 .2019 Article recommended for publishing 09.25.2019 